Article

\title{
A Smart Irrigation Tool to Determine the Effects of ENSO on Water Requirements for Tomato Production in Mozambique
}

\author{
Eduardo Gelcer ${ }^{1,2}$ (1) Clyde W. Fraisse ${ }^{1, *}$, Lincoln Zotarelli ${ }^{3}$, Daniel Perondi ${ }^{1}$, \\ Hipólito A. Malia ${ }^{4}$, Carvalho C. Ecole ${ }^{4}$ and Kati W. Migliaccio ${ }^{1}$ \\ 1 Department of Agricultural and Biological Engineering, University of Florida, Gainesville, FL 32611, USA; \\ emgelcer@yahoo.com.br (E.G.); dperondi@ufl.edu (D.P.); klwhite@ufl.edu (K.W.M.) \\ 2 CAPES Foundation, Ministry of Education of Brazil, Brasilia, DF 70040-020, Brazil \\ 3 Horticultural Sciences Department, University of Florida, Gainesville, FL 32611, USA; lzota@ufl.edu \\ 4 Mozambique Institute of Agricultural Research, Maputo 3658, Mozambique; litomalia@gmail.com (H.A.M.); \\ ccecole@gmail.com (C.C.E.) \\ * Correspondence: cfraisse@ufl.edu; Tel.: +1-352-392-1864 (ext. 271)
}

Received: 29 September 2018; Accepted: 5 December 2018; Published: 10 December 2018

\begin{abstract}
Irrigation scheduling is used by growers to determine the right amount and timing of water application. In most parts of Mozambique, $90 \%$ of the total yearly precipitation occurs from November to March. The El Niño Southern Oscillation (ENSO) phenomenon influences the climate in Mozambique and affects the water demand for crop production. The objectives of this work were to quantify the effects of ENSO phenomenon on tomato crop water requirements, and to create the AgroClimate irrigation tool (http:/ / mz.agroclimate.org/) to assist farmers in improving irrigation management. This study was based on daily grid-based climate information from 1983 to 2016 from the Climate Forecast System Reanalysis. Daily crop evapotranspiration was calculated by Hargreaves equation and crop coefficients. This tool is available online and considers different planting dates, ENSO phases, and crop growing season lengths. Irrigation needs varied from less than $250 \mathrm{~mm}$ per growing cycle during winter to $550 \mathrm{~mm}$ during spring. Both El Niño and La Niña influenced the irrigation scheduling, especially from November to March. El Niño periods were related to increased water demand due to drier and warmer conditions, while the opposite was observed for La Niña. The ENSO information might be used to understand climate variability and improve tomato irrigation scheduling in Mozambique.
\end{abstract}

Keywords: Irrigation scheduling; Solanum lycopersicum; El Niño; water stress; decision support system; climate variability

\section{Introduction}

Tomato (Solanum lycopersicum) is the horticultural crop with the third largest area in Mozambique, only behind pumpkin and cucumber. Tomatoes are produced by more than 270,000 growers using an area larger than 36,000 ha [1]. Family agriculture accounts for approximately $84 \%$ of the tomato production area in the country [2]. For most areas in Mozambique, $90 \%$ of the rain occurs from November to March. However, the main tomato production season extends from March to October, which is the period with proper air temperatures for the crop development [3]. Therefore, irrigation is an essential practice for tomato production in the country. The irrigated area in Mozambique is around 118,000 ha [2], however, only $34 \%$ of the area is operational [4].

An adequate irrigation schedule defines the correct amount of water and the correct time for its application [5] and is beneficial during both dry and rainy seasons by providing more efficient use of 
water resources and less irrigation related leaching of agrochemicals. Patane et al. (2012) [6] observed that water stress during initial growth negatively affected tomato marketable yield. However, water restriction after flowering did not result in significant yield losses. Allen et al. (1998) [7] reported that tomato crops can tolerate up to $40 \%$ water deficit, while Marouelli et al. [8] reported that the tolerable deficit varies from $20 \%$ for sandy soils to $40 \%$ for clay soils.

Since growers cannot modify the weather conditions by modifying the microenvironment (e.g., cultivation under high tunnels) to avoid its variability, they have to understand how the variability occurs to benefit from it and to minimize its negative effects [9]. The El Niño-Southern Oscillation is the main phenomenon influencing climate variability around the world [9-13] and in Mozambique [3,14,15]. In Mozambique, the warm phase of ENSO (El Niño) is related to drier and warmer conditions in most parts of the country from December to May, while the cold phase of ENSO (La Niña) has the opposite effects during the same period [16]. Few authors have reported the effects of ENSO on horticultural production in Africa in general, and in Mozambique in particular. ENSO phenomenon has greater impact on tomato crop planting date during the Southern hemisphere fall and spring seasons than during the winter and summer [3]. While ENSO influences the weather patterns during the summer, the air temperature and rainfall amounts are excessively high for tomato production, independently of the ENSO phase. Stige et al. (2006) [12] asserts that food production in Africa might be severely affected by ENSO conditions and observed 20-50\% yield reduction for row crops in Southern Africa during strong El Niño years. El Niño has been related to early start and termination of the rainy season and inconsistent rain events, causing increased dry spells [17].

The AgroClimate Mozambique (http:/ / mz.agroclimate.org/) [16] is a decision support system created to organize climate and weather information in a user-friendly way, to inform the impacts of weather on specific crops, as well as to provide management adaptation suggestions aimed at reducing crop production risk and increasing resource use efficiency. As climate information is more valuable for growers if there is a clear management adaptation related to it [9], AgroClimate aims to assist growers, extension agents and researchers in the use of weather information to make management adaptations to reduce risks associated with climate variability. The AgroClimate Mozambique provides knowledge regarding the climate inter and intra-years variability, as well as information to help farmers make both strategic pre-season decisions and in-season operational decisions [18].

Due to lack of weather-related information and lack of soil sensors, growers typically make crop water management decisions based on field observations rather than on field measurements or on model estimations. An alternative solution for farmers is to use simple models based on crop evapotranspiration. These models have been developed to define the water requirement by a specific crop and to improve irrigation efficiency [5,19]. Muñoz-Carpena et al. (2005) [20] observed similar tomato crop yield when comparing traditional irrigation management with irrigation schedules based on historical evapotranspiration, tensiometers, and granular matrix sensors. The schedule based on historical evapotranspiration applied $45 \%$ less water than the traditional management, $39-51 \%$ more water than the treatments using tensiometers, and similar amount when compared with the matrix granular sensor. The last one is a more modern sensor, made of a porous material, similar to a tensiometer and that has been used in automatic irrigation systems. Water savings have been reported when using evapotranspiration-based irrigation schedule compared to traditional (time-based) irrigation schedule for turfgrass [21,22]. Vellidis et al. (2016) [23] observed that ET-based irrigation schedule for cotton production over performed traditional schedule in yield, water use efficiency, and water application. The ET-based method had performance comparable with soil moisture sensors. However, model application is limited due to the large amount of inputs required, especially weather information that is not freely and widely available in Mozambique.

As ENSO is related to climate variability, and environmental conditions directly influence the water requirement of crops, the first objective of this study was to identify how the ENSO phenomenon affects crop water requirements for tomato production in Mozambique. The second objective was 
to develop the AgroClimate Mozambique irrigation tool (http:/ /mz.agroclimate.org/) [16] to assist farmers in improving irrigation management, and reducing plant water stress and water losses.

\section{Materials and Methods}

\subsection{Study Area}

Located in southeastern Africa, between the latitudes $-10^{\circ} 28^{\prime}$ and $-26^{\circ} 52^{\prime}$, longitudes $30^{\circ} 22^{\prime}$ and $40^{\circ} 83^{\prime}$, with elevations varying from 0 to $2400 \mathrm{~m}$ above sea level (Figure 1a), Mozambique has strong maritime influence, since the coast extends for more than $2400 \mathrm{~km}$ [24]. Several climates are observed within the country due to the latitude and elevation variability. Based on the Köppen-Geiger classification (Figure 1b), the climate in Mozambique is equatorial savannah with dry winters (Aw) with some areas having hot semi-arid climate (BSh), while higher-elevation regions have warm temperate climate with dry winters and hot summers (Cwa) [25]. In the Western part of Gaza, one of the driest regions of the country, the yearly rainfall is around $200 \mathrm{~mm}$, while in the Zambezia province, the annual rainfall is around $1200 \mathrm{~mm}$ [26]. In most parts of Mozambique, more than $90 \%$ of the annual rainfall occurs from November to March while less than 10\% occurs from April to October. In November, the average maximum air temperature may reach $40^{\circ} \mathrm{C}$ in lower elevation regions in the central part of the country. In June and July, the air temperature might be as low as $6{ }^{\circ} \mathrm{C}$ in high elevations at the Manica, Tete, and Niassa provinces. The yearly average air temperature varies between 20 and $26^{\circ} \mathrm{C}$ throughout the country [16].

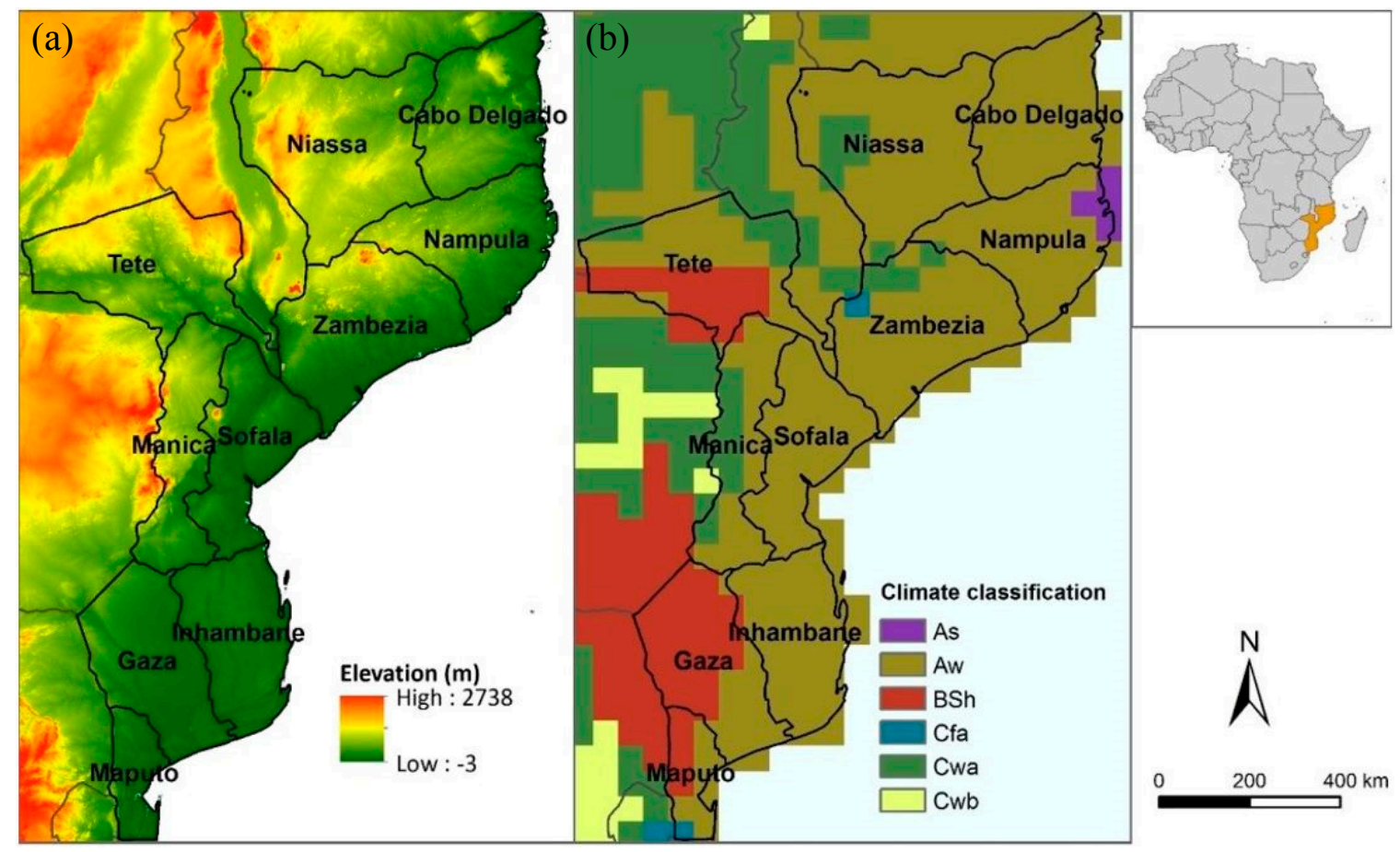

Figure 1. (a) Elevation (MapMart, 2014 (http:/ / www.mapmart.com/)) and (b) climate of Mozambique using Köppen classification [25]. As = Equatorial savannah with dry summer, Aw = Equatorial savannah with dry winter, BSh $=$ Hot Steppe climate, $\mathrm{Cfa}=$ Warm temperate climate, fully humid with hot summer, $\mathrm{Cwa}=$ Warm temperate climate with dry winter and hot summer, and Cwb = Warm temperate climate with dry winter and warm summer. Source: Gelcer et al. (2018) [3].

\subsection{Crop Evapotranspiration}

The water requirement of a crop is the same as the crop evapotranspiration $\left(\mathrm{ET}_{\mathrm{C}}, \mathrm{mm} \mathrm{day}^{-1}\right)$, which is calculated by multiplying the reference evapotranspiration $\left(\mathrm{ET}_{\mathrm{O}}, \mathrm{mm}^{\mathrm{day}}{ }^{-1}\right)$ by a crop coefficient $\left(\mathrm{K}_{\mathrm{C}}\right)$ [7]: 


$$
\mathrm{ET}_{\mathrm{C}}=\mathrm{ET}_{\mathrm{O}} * \mathrm{~K}_{\mathrm{C}}
$$

the $\mathrm{K}_{\mathrm{C}}$ values vary depending on the crop development phase. For the present studies, the $\mathrm{K}_{\mathrm{C}}$ values were based on References $[7,8,27]$ (Table 1 ). The length of each growing phase was estimated based on Reference [7] using the same relative length of each phase for all growing cycles.

Table 1. Days after planting and crop coefficient $\left(\mathrm{K}_{\mathrm{C}}\right)$ for each development phase for three generic varieties of tomato with 75-d, 90-d and 105-d growing cycle. Based on [7,8,27].

\begin{tabular}{ccccc}
\hline \multirow{2}{*}{ Development Phase } & \multicolumn{3}{c}{ Days After Planting } & \multirow{2}{*}{$\mathbf{K}_{\mathbf{C}}$} \\
\cline { 2 - 4 } & 75-d Cycle & 90-d Cycle & 105-d Cycle & \\
\hline Initial growth & $0-17$ & $0-20$ & $0-24$ & 0.60 \\
Crop development & $18-39$ & $21-47$ & $25-55$ & 0.90 \\
Late season & $40-61$ & $48-74$ & $56-86$ & 1.15 \\
Harvest & $60-75$ & $75-90$ & $87-105$ & 0.90 \\
\hline
\end{tabular}

The $\mathrm{ET}_{\mathrm{O}}$ was calculated using the Hargreaves method [28], since this method only requires air temperature data and showed low error for Mozambique when compared to $\mathrm{ET}_{\mathrm{O}}$ estimated using the FAO-56 Penman-Monteith equation $[29,30]$, which is the standard equation to estimate $\mathrm{ET}_{\mathrm{O}}$. The Hargreaves equation is:

$$
\mathrm{ET}_{\mathrm{O}}=0.0023\left(\mathrm{~T}_{\mathrm{avg}}+17.8\right)\left(\mathrm{T}_{\max }-\mathrm{T}_{\min }\right)^{0.5} \mathrm{R}_{\mathrm{a}}
$$

where, $\mathrm{T}_{\max }$ and $\mathrm{T}_{\min }$ are maximum and minimum air temperatures $\left({ }^{\circ} \mathrm{C}\right) ; \mathrm{T}_{\text {avg }}$ is the daily mean air temperature $\left({ }^{\circ} \mathrm{C}\right)$, based on the average of $\mathrm{T}_{\max }$ and $\mathrm{T}_{\min }$; and $\mathrm{R}_{\mathrm{a}}$ is extraterrestrial radiation $\left(\mathrm{MJ} \mathrm{m}^{-2} \mathrm{~d}^{-1}\right)$ [7]. Daily historical gridded-based air temperature information was obtained from Climate Forecast System Reanalysis (CFSR) [31] with a spatial resolution of $0.25^{\circ} \times 0.25^{\circ}$ for the period between 1983 and 2016.

\subsection{Irrigation Schedule}

The growing season length varies depending on the variety and period of the year. Therefore, three possible growing cycles represented by three generic (hypothetical) varieties with 75-day, 90-day, and 105-day growing cycle (from planting to harvest), typical in Mozambique, were selected. The irrigation schedule used 24 possible planting dates per year, the first and the sixteenth day of each month. For each planting date and crop variety, the average daily ET $_{C}$ based on all years with available data was determined. As most farmers in Mozambique have limited or no access to internet, the irrigation schedule does not need access to in-season weather information and was based on average of historical values of $\mathrm{ET}_{\mathrm{C}}$. For each variety, daily $\mathrm{ET}_{\mathrm{C}}$ was calculated using the daily $\mathrm{ET}_{\mathrm{O}}$ and the corresponding $\mathrm{K}_{\mathrm{C}}$ for the crop development stage (Table 1). Rainfall was not considered in the tool because the average historical rainfall does not well represent the year-to-year rainfall variability and the observed daily rainfall might have large deviation from the historical average. Therefore, assuming the occurrence of rainfall events could result into large errors in the model and in the irrigation scheduling. To offset this issue, the tool indicates how the rainfall events can affect the irrigation schedule. In addition, rainfall has low importance during the main tomato growing season, which extends from March to October.

For ease of management and to reduce the number of adjustments in the irrigation management and equipment during the growing season [5,32], the irrigation amount was kept constant for a 10-day period, similar to the irrigation scheduling tool developed by Migliaccio et al. (2015) [22]. The type of irrigation was not included since most growers either use surface irrigation, such as border strip irrigation in a not well-prepared terrain, which has low efficiency, or hand water the crop. A few more advanced growers use drip-irrigation. This variability in irrigation systems around the country 
results in high efficiency variability. The water depth per irrigation event was determined by dividing the 10-day total ET $_{C}$ by the number of irrigation events in that period. The number of events varied depending on the crop development stage and on the root zone depth. Early growth stages received irrigation more frequently at lower rates due to shallower root zones, while the crop development and late season phases had higher application rates [5]. As recommended by Marouelli et al. (2008) [8], irrigation events ceased five days before the end of the season to increase the uniformity of the tomato fruits and soluble solid content, and to reduce the chances of disease occurrence. The irrigation tool provides the frequency of irrigation events as well as the water depth. Table 2 shows the frequency of application for each 10-day period.

Table 2. Recommended interval between irrigation events for three crop varieties (75- $d, 90-d$, and 105-d growing cycles) from day 1 after planting (DAP) until the end of the cycle.

\begin{tabular}{cccccc}
\hline \multicolumn{2}{c}{ 75-d Cycle } & \multicolumn{2}{c}{ 90-d Cycle } & \multicolumn{2}{c}{ 105-d Cycle } \\
\hline DAP & Irrig. Freq. & DAP & Irrig. Freq. & DAP & Irrig. Freq. \\
\hline $1-10$ & Daily & $1-10$ & Daily & $1-10$ & Daily \\
$11-20$ & 2 day & $11-20$ & 2 day & $11-20$ & 2 day \\
$21-30$ & 3 day & $21-30$ & 3 day & $21-30$ & 2 day \\
$31-40$ & 3 day & $31-40$ & 3 day & $31-40$ & 3 day \\
$41-50$ & 3 day & $41-50$ & 3 day & $41-50$ & 3 day \\
$51-60$ & 3 day & $51-60$ & 3 day & $51-60$ & 3 day \\
$61-70$ & 4 day & $61-70$ & 3 day & $61-70$ & 3 day \\
$71-75$ & No irrig. & $71-80$ & 4 day & $71-80$ & 3 day \\
& & $81-85$ & 4 day & $81-90$ & 4 day \\
& - & $85-90$ & No irrig. & $91-100$ & 4 day \\
& - & & - & $101-105$ & No irrig. \\
\hline
\end{tabular}

\subsection{Irrigation Schedule Pre-Evaluation}

A soil water balance for each year was performed to quantify the daily soil water deficit and verify if the proposed irrigation schedule meets the crop water demand. The water balance used the methodology proposed by Woli et al. (2012) [33] to estimate soil water content:

$$
\mathrm{W}_{\mathrm{i}}=\mathrm{W}_{\mathrm{i}-1}+\mathrm{I}_{\mathrm{i}}-\mathrm{ETa}_{\mathrm{i}}-\mathrm{D}_{\mathrm{i}}-\mathrm{R}_{\mathrm{i}}
$$

where, $W_{i}$ and $W_{i-1}$ are the available water $(\mathrm{mm})$ in the root zone on $i$ th and $(i-1)$ th days, $I_{i}$ is the irrigation amount $(\mathrm{mm}), \mathrm{ETa}_{\mathrm{i}}$ is the actual crop evapotranspiration $(\mathrm{mm}), \mathrm{D}_{\mathrm{i}}$ is drainage $(\mathrm{mm})$, and $\mathrm{R}_{\mathrm{i}}$ is runoff $(\mathrm{mm})$ on the $i$ th day. Drainage and runoff were calculated, as described by Woli et al. (2012) [33]. The only input of water was through irrigation based on the calendar. Rainfall was not included in the soil water balance since the irrigation tool does not take into account rainfall events, similar to what was presented by Migliaccio et al. (2015) [22].

To adjust the water balance for a tomato crop, daily $\mathrm{ET}_{\mathrm{C}}$ replaced daily $\mathrm{ET}_{\mathrm{O}}$ to calculate $\mathrm{ETa}_{\mathrm{i}}$ and the root depth had a linear growth from $6 \mathrm{~cm}$ on the planting day to $40 \mathrm{~cm}$ on the 40th day of the cycle. Soil field capacity (FC) and permanent wilting point (PWP) were calculated using the soil information provided by ISRIC - World Soil Information (2013) [34] and the methodology proposed by Rawls et al. (1982) [35].

For irrigation management, the readily available water (RAW) is the operating range of soil water content [36]. The RAW is the fraction (p) of the total available water (TAW) that can be extracted from the root zone without suffering water stress. If the soil water content is between RAW and TAW, the crop does not suffer with water stress [7]:

$$
\begin{gathered}
\mathrm{RAW}=\mathrm{p} * \mathrm{TAW} \\
\mathrm{TAW}=1000\left(\theta_{\mathrm{FC}}-\theta_{\mathrm{PWP}}\right) * \mathrm{Z}_{\mathrm{r}}
\end{gathered}
$$


where, $\theta_{\mathrm{FC}}$ and $\theta_{\mathrm{PWP}}$ are the soil water content at soil field capacity and permanent wilting point $\left(\mathrm{m} \mathrm{m}^{-3}\right)$, and $\mathrm{Z}_{\mathrm{r}}$ is the rooting depth $(\mathrm{m})$. According to Marouelli et al. (2008) [8], $\mathrm{p}$ for tomato varies from 0.4 for clay soils to 0.2 for sand soils.

\subsection{Influence of ENSO on Irrigation Schedule}

Besides providing the irrigation schedule based on all years with data, the online irrigation tool provides a schedule for each ENSO phase to help growers utilize the expected ENSO cycle for improving their irrigation management during the season. Each one of the 792 growing cycles (33 years $\times 24$ planting dates per year) was classified as El Niño, La Niña, or Neutral using the Oceanic Niño Index (ONI) from NOAA (http:/ / origin.cpc.ncep.noaa.gov/products/analysis_monitoring/ensostuff / ONI_v5.php) (Appendix A). Then, the average daily ET $_{C}$ per ENSO phase per planting date was calculated and grouped, as described in the section Irrigation schedule.

To identify how ENSO warm and cold phases influence tomato water requirements, crop water requirement maps were created showing the deviation from historical average (average for all years) when El Niño or La Niña was present. For this evaluation, a generic variety with 90 day growing cycle was selected. The average of cumulative $\mathrm{ET}_{\mathrm{C}}$ for all years with available data was subtracted from the cumulative average $\mathrm{ET}_{\mathrm{C}}$ for each ENSO phase. Therefore, a negative or positive deviation indicates that a situation having, respectively, lower or higher crop water requirement.

\subsection{AgroClimate Tool Development}

The irrigation tool available on AgroClimate Mozambique (http:/ / mz.agroclimate.org/rega) is used as a plug-in in CMS Wordpress and was developed using the HTML5, CSS3, and JavaScript languages (Figure 2). The HTML (Hyper Text Markup Language) allows text interpretation by browsers, providing new features [37] and its last generation is the HTML5. The CSS (Cascading Style Sheets) improves the presentation of HTML documents [38], while the CSS affects the format of buttons, address inputs, dialog boxes, and windows. JavaScript is an interpreted language with object-orientation capabilities used in web browsers. The scripts built with JavaScript can interact with the users, control the web browsers, and alter the document content showed in a browser window [39].

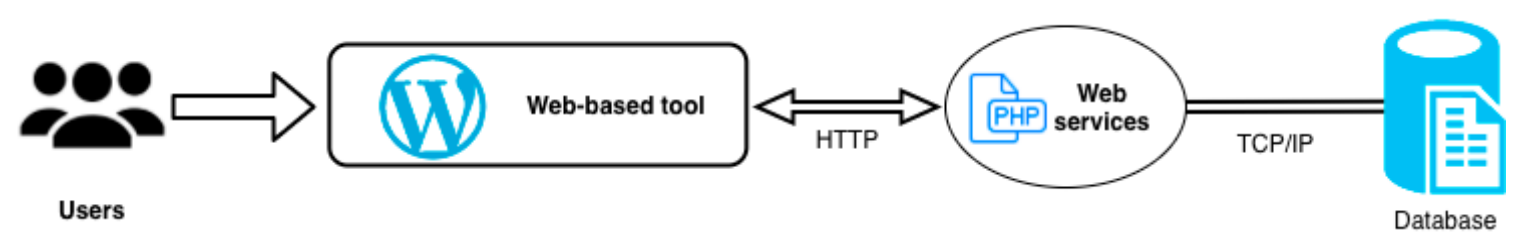

Figure 2. Schematic representation of the creation of the irrigation tool available on AgroClimate Mozambique.

The tool structure (coding) and layout are in Portuguese, the official language of Mozambique. It allows local web-designers to administrate and maintain the tool, and increase the interaction and understanding of the tool by growers. The users have the option to translate the tool to other languages using a Google plug-in. The current study uses screenshots in English to increase the understanding of the tool. All images can be easily downloaded and stored for posterior use to increase outreach opportunities and use of the tool in locations with restricted or no access to internet.

The tool was created based on tools available on AgroClimate Mozambique [3,16], on the AgroClimate version for the Southeast USA [9], and on FAWN [40]. Moreover, the creation of this tool considered suggestions from growers and extension agents from Mozambique, from researchers from the Mozambique Agricultural Research Institute (IIAM), and from the University of Florida. The tool can be easily adapted to other crops, since it relies on the combination of $\mathrm{ET}_{\mathrm{O}}$ and $\mathrm{K}_{\mathrm{C}}$ to determine an irrigation schedule. This approach has been widely used to determine water demand for several 
crops $[5,7,27,41,42]$. For that, the only required parameters are the other crops $K_{C}$, length of each growing phase, and total growing season length.

When the user accesses the irrigation tool, the modules and the content are displayed. The first module is composed of the planting date, the second one of the ENSO phase, the third one of the crop type, and the fourth one of the growing season length. When the tool is loaded, a default selection is used, but the user can select the best combination that represents their field conditions.

\section{Results and Discussion}

On the pre-evaluation of the tool, the proposed schedule was applied for the 34 years with weather information. The lowest simulated fraction of total available soil water was observed for the growing cycles starting from March to May. For the cycles starting from June to February, the use of the tool resulted in a water content in the soil close to the field capacity and the absence of crop water stress. Between March and May, the fraction of total available soil water was higher than 0.8 in all situations, which indicates that the soil water depletion varied from nearly zero to $20 \%$. Marouelli et al. (2008) [8] asserted that tomato crops can tolerate up $40 \%$ of depletion fraction in clay soils and up to $20 \%$ in sand soils. According to Allen et al. (1998) [7], the tomato crop can tolerate up to $40 \%$ of soil water depletion without affecting the yield. These results indicate that the proposed irrigation schedule is appropriate since the soil water depletion would not negatively affect the crop.

The irrigation tool in AgroClimate Mozambique (http:/ / mz.agroclimate.org/rega) presents the daily crop water demand for a 10-day period for Mozambique. For that, the user must select the planting date, ENSO phase, crop type, and growing season length. The maps are then generated, showing the irrigation depth per event, in millimeters, the information of irrigation frequency, and a table with days to delay application in the case of rain events (Figure 2). Different maps show the irrigation water depth required for a 10-day period within the growing cycle. The schedule was organized in 10-day periods for easiness of management and due to low variability of $\mathrm{ET}_{\mathrm{O}}$ within a period. The average $\mathrm{ET}_{\mathrm{O}}$ of a 5-day period can be used to determine daily water requirement for the subsequent 15-day period [43]. Migliaccio et al. (2015) [22] observed different application schedules for irrigation controllers that use on-site evapotranspiration estimative and irrigation schedule based on the nearest weather station. However, they did not observe difference in total water applied and turf grass quality. Vellidis et al. (2016) [23] tested a similar system in Florida and Georgia, USA, and found precise irrigation requirements using an evapotranspiration model. However, their system is based on automated weather stations with real-time data. Such a system using real-time weather data could not be implemented in Mozambique due to its cost. Moreover, farmers do not access the internet frequently, therefore, daily updates using real-time weather data would not result in an effective management adaptation.

The resulting irrigation scheduling tool displays several maps with the irrigation depth per irrigation event, the irrigation frequency, and how many days the irrigation event should be delayed in case of a rainfall event (Figure 3). The Section A (Figure 3A) shows information about the AgroClimate Mozambique website, the current ENSO phase, and the menu bar. On Section B (Figure 3B), the user selects the crop management characteristics (planting date and growing cycle), and the years to consider according to the ENSO phases (El Niño, La Niña, and Neutral) or all years. Once the user makes any selection, the maps on Section C (Figure 3C) are updated to match the selection. The Section D (Figure 3D) has a suggestion of irrigation frequency, which varies depending on the crop development stage, irrigation system, and irrigation depth for the period. The Section E (Figure 3E) indicates how rainfall events can affect the schedule. Depending on the amount of rain, the irrigation might be delayed for one, two, or three days. All images available on the website are available for download (Section F, Figure 3F) to facilitate their use when internet access is not available or restricted.

This tool can be used by extension agents and farmers to create an irrigation schedule for the upcoming season and to make in-season decisions. Applying the correct amount of water at the right timing is fundamental for increased water use efficiency and for a successful tomato crop [44,45], 
as well as for reducing labor, costs, and nutrients leaching. During the first ten days of the crop development, the tool can be very helpful to define irrigation needs. During this period, the tomato crop is very sensitive to water stress due to adaptation to the field conditions and due to shallow roots system. However, excess of irrigation can increase the occurrence of diseases and may reduce a crops final stand [46]. During vegetative growth, moderate water stress may not affect yield [45] and can contribute for root development $[46,47]$. However, more severe stress may reduce the total biomass, yield, and fruit size [6,48]. Even if moderate stress may benefit the crop development, the tool was designed to result in nearly no water stress since the soils in Mozambique are well drained [49] and waterlogging is less likely to occur than water stress.

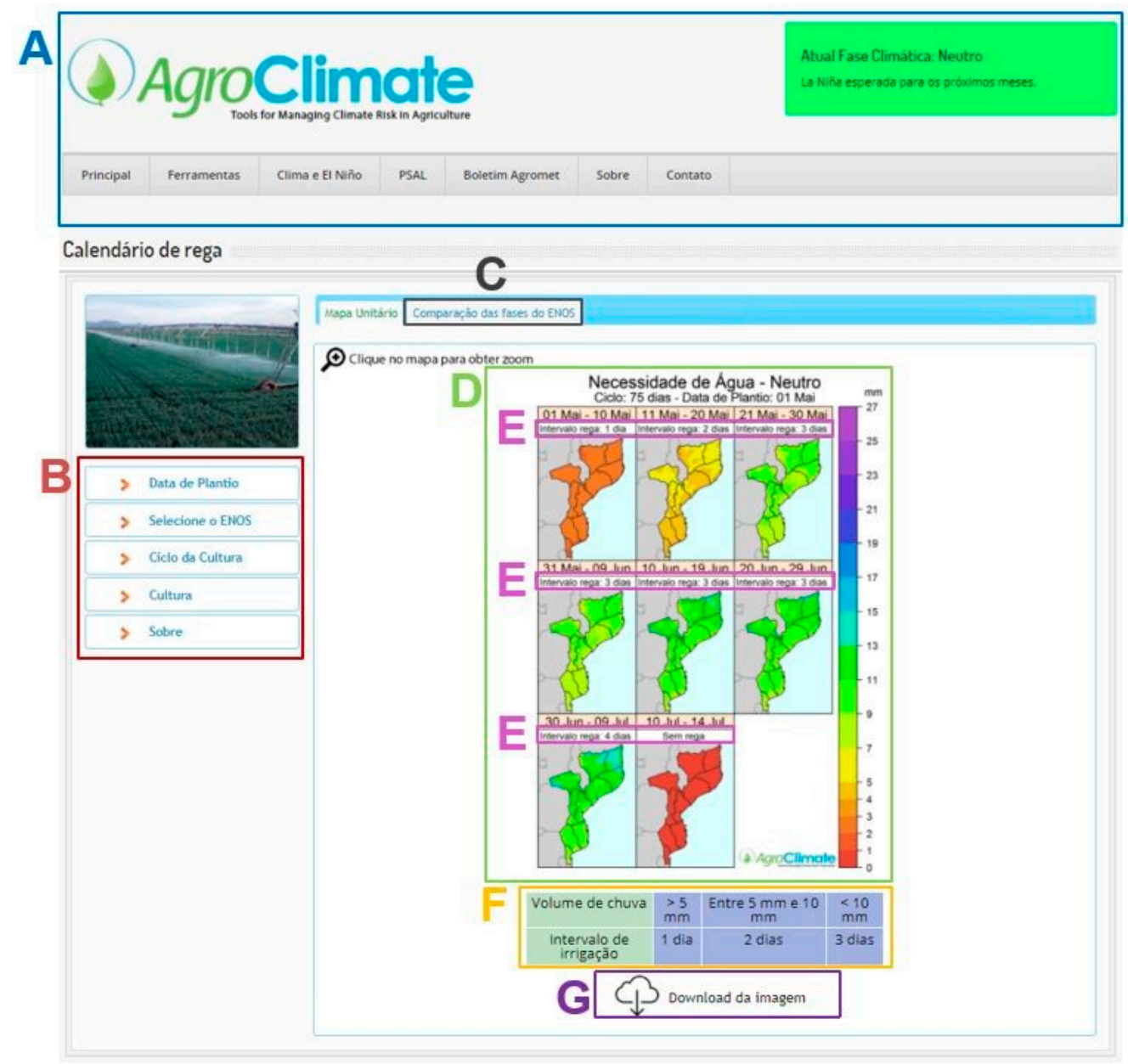

Figure 3. Screenshot of the irrigation scheduling tool in AgroClimate Mozambique (http://mz. agroclimate.org/rega). It shows the daily average water requirement for 90 -day cycle tomato crops planted on May 1st. A shows information about the AgroClimate Mozambique website, the current ENSO phase, and the menu bar; $\mathrm{B}$ allows the user to select the management options more similar to what is observed in the field; C shows the ENSO phases comparison; D is the irrigation depth for each 10-day period; $\mathrm{E}$ is the irrigation frequency; $\mathrm{F}$ indicates how rainfall events can affect the schedule and depending on the amount of rain, the irrigation might be delayed for one, two, or three days; and G allows the download of the images.

Flowering and fruit development are the most sensitive periods for tomato crop $[7,46,48]$. For these specific crop stages, the online tool can be extremely helpful. Moderate to severe water stress can decrease plant height, stem diameter [47], pollen viability and fruit size [46], and can significantly reduce yield [48]. Differently from the fruit development phase, the maturation phase has a reduced water consumption $[27,50]$ and the irrigation events should occur in larger intervals [46]. 
Moderate stress during this period, results in slightly reduction in yield but increased brix and fruit quality $[46,48,50]$. Excess of irrigation increase the risk of diseases, but severe stress may result in high yield and quality losses.

The ENSO information in the tool can assist farmers and extension agents to determine crop irrigation needs considering climate variability. ENSO plays a key role to define irrigation needs from February to April. Before February, the conditions are not proper for tomato crop development independently on the ENSO phase [3], and after April, the conditions are similar for all ENSO phases. Due to warmer conditions during El Niño, the irrigation needs are higher than during La Niña cycles and long-term averages. When combined with ENSO forecast, the online tool can be used by farmers to define the irrigation schedule for the upcoming season.

For researchers and irrigation engineers, the online tool helps to set up irrigation trials and design irrigation systems. When setting up a trial in a new location, researchers can use the tool as a baseline to define crop water requirements. The minimum requirements for pump size and irrigation equipment can also be define based on the information generated by the irrigation tool combined with the size of the irrigated area.

\subsection{Spatial and Temporal Variability of Water Requirements}

The total crop water requirement is the total crop evapotranspiration $\left(\mathrm{ET}_{\mathrm{C}}\right)$ throughout the growing season. The $\mathrm{ET}_{\mathrm{C}}$ is a function of the environmental conditions (air temperature, solar radiation, relative humidity, and wind speed), and crop characteristics. As the crop and management practices are the same for all maps in Figure 4, the variability in environmental conditions is the only factor causing variation of water needs among the maps. Overall, the locations with lower elevation have higher crop water requirement due to higher air temperature, while locations at higher elevations have lower crop water requirement. At lower elevations in Tete, the average total $\mathrm{ET}_{\mathrm{C}}$ for a single season can be as high as $550 \mathrm{~mm}$, while at high elevations (> $600 \mathrm{~m}$ ) it does not exceed $400 \mathrm{~mm}$. The highest cumulative $\mathrm{ET}_{\mathrm{C}}$ values occur for tomato crops planted from September to December in the central and Southern regions, especially in Zambezi, Tete, and Sofala, where the average total $\mathrm{ET}_{\mathrm{C}}$ is always above $400 \mathrm{~mm}$. The minimum values of average total $\mathrm{ET}_{\mathrm{C}}$ are observed in Niassa for crops planted from February to August when the values might be lower than $250 \mathrm{~mm}$.

While September is the end of winter, the water demand is similar to the one observed during summer (December to February). In September, the rainfall amount is below $15 \mathrm{~mm}$ for most parts of the country resulting in high air temperatures, low relative humidity, and water demands similar to summer. During summer, the air temperatures are slightly higher than in September, but the relative humidity is also higher and rainfall is abundant, causing an overall reduction in ET $_{C}$. Moreover, the crops planted in September have part of the growing cycle in October and November, which are the months with the highest air temperatures in several parts of the country [16]. From November to March the irrigation schedule tool might be used to plan the irrigation events to reduce soil water percolation and to avoid the effects of dry spells, especially during critical periods, such as crop establishment, flowering, and fructification [46]

Tomato crops planted from April to June have the lowest water requirements because they grow in the period with the lowest air temperatures of the year, resulting in lower $\mathrm{ET}_{\mathrm{C}}$. From May to July, the average air temperature varies from 16 to $24{ }^{\circ} \mathrm{C}$ for most parts of the country. During this period, the irrigation scheduling tool assists farmers to define how much and when water should be applied. As $90 \%$ of the rain occurs from October to March, from April to September the water resources are scarce and water for irrigation is limited, and the irrigation tool might be used to optimize water use and reduce crop water stress. Migliaccio et al. (2015) [22] used an irrigation scheduling tool and observed water savings when compared with time-based irrigation, indicating that evapotranspiration-based methods can be employed to improve irrigation management. For Vellidis et al. (2016) [23], evapotranspiration-based schedule provided similar results to soil sensor-based schedule. 


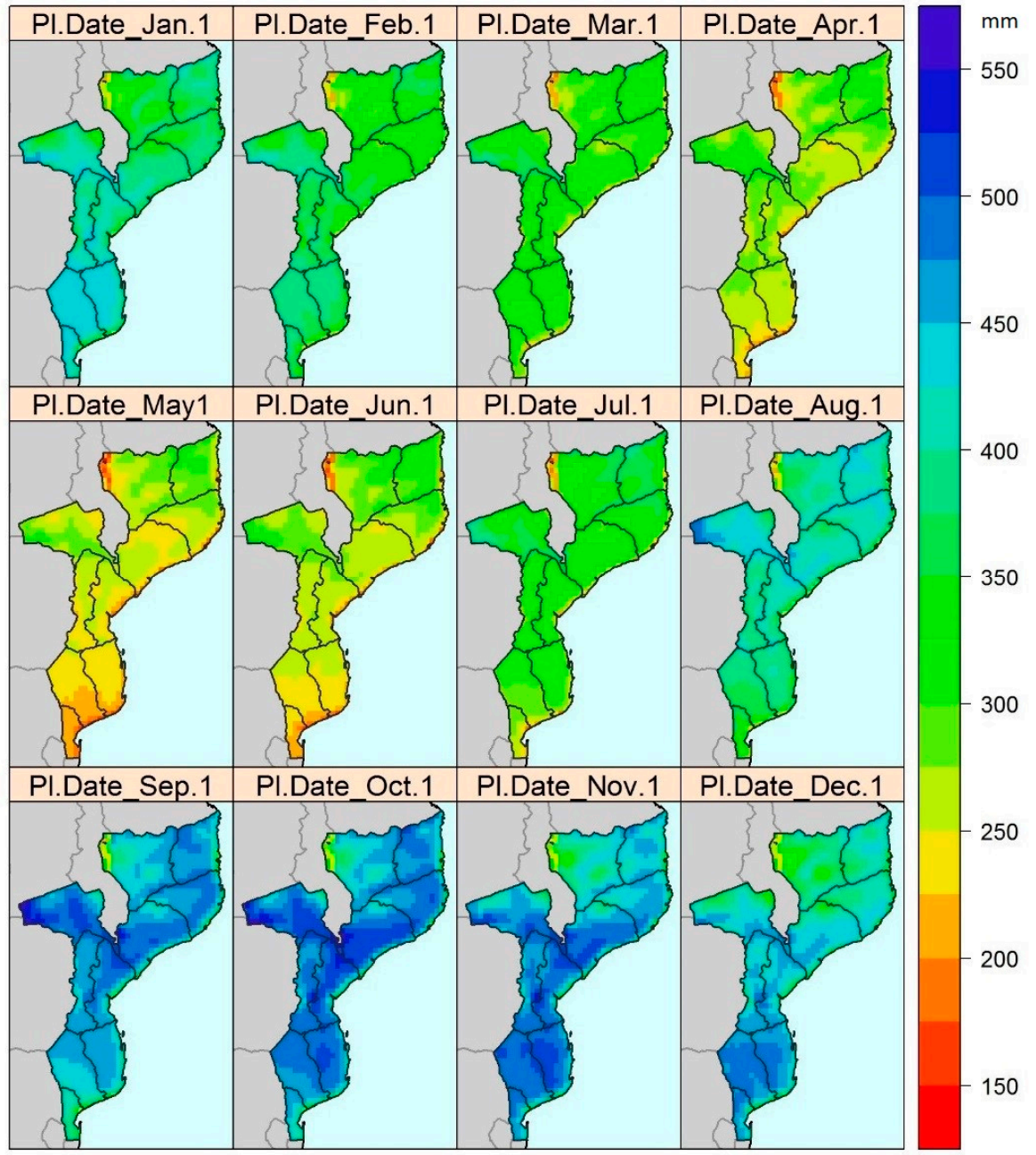

Figure 4. Spatial and temporal variability of tomato crop total water requirement $(\mathrm{mm})$ for Mozambique for a generic variety with 90-day growing cycle planted in the first day of each month.

\subsection{ENSO Influence on Water Requirement}

As ENSO is directly related to variability of rainfall and air temperature in Mozambique, especially during summer months, it also affects the water demand by crops. Both El Niño and La Niña showed influence in water demand, mainly from November to March (Figures 5 and 6). During El Niño, the rain amount is lower during this period causing higher incoming solar radiation and air temperature, and lower relative humidity, resulting in higher $\mathrm{ET}_{\mathrm{C}}$. The opposite happens during La Niña, causing reduced water demand. For most parts of Mozambique, especially central and Southern parts, the deviation of crop water requirement varies from 10 to $50 \mathrm{~mm}$ during El Niño and from - 10 to $-40 \mathrm{~mm}$ during La Niña. In some regions, the difference between El Niño and La Niña varies from 30 to $50 \mathrm{~mm}$, which represents about $10 \%$ of the total crop water demand for the whole cycle. El Niño also presented positive deviations during April in most provinces, during May in the central region, and during October in the South. La Niña had negative deviation in April, June and October in the central part of the country. ENSO had low influence on crop water requirements from May to September since ENSO has lower influence in Mozambique's climate during this period. These results are in agreement with previous ENSO studies in Mozambique. Mavie (1999) [14] and Lobo (1999) [15] observed significant positive deviation for air temperature during El Niño events during summer and no significant difference during winter, which was related to increased crop water requirement during El Niño years. 
Farmers try to plant tomato in February or March when the conditions are not appropriated for the crop development to benefit from higher market price caused by the lack of product available [51]. In these cases, the ENSO information has higher value since this is the period with increased influence of ENSO in the water demand by the crop. The irrigation tool can be used in educational programs to help farmers to understand how crop water requirements vary during the year, and from year-to-year. The ENSO forecast combined with the tool provides information for decision makers to determine if the water demand is above, below or equal the average of other years. More spatial and temporal information can be obtained from the irrigation tool (http:/ / mz.agroclimate.org/rega) [16].

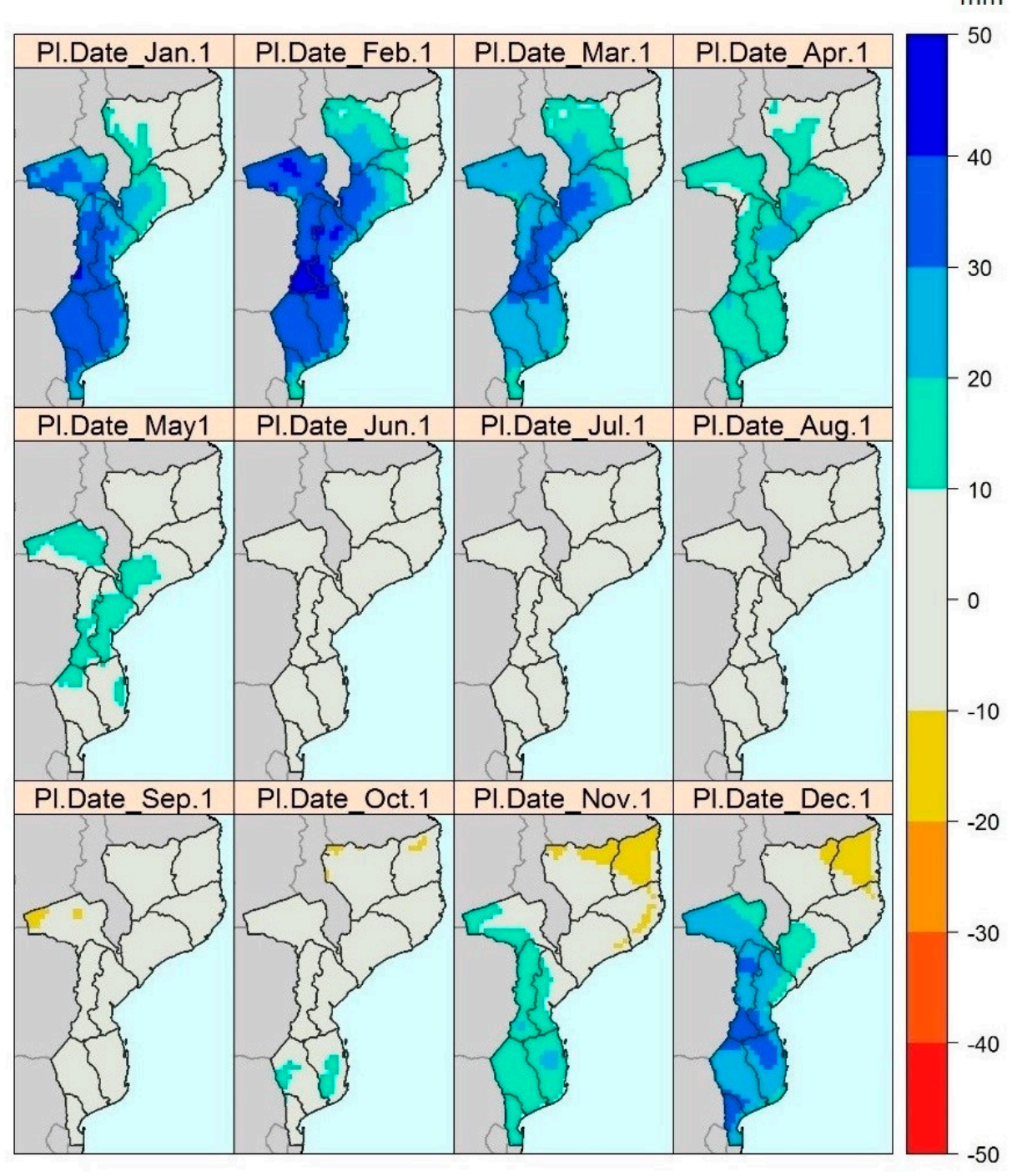

Figure 5. Spatial and temporal of deviation for El Niño of tomato crop total water requirement (mm) for Mozambique for a generic variety with 90-day growing cycle planted in the first day of each month.

The irrigation scheduling tool available on AgroClimate Mozambique has some limitations based on the methods used for its development. The crop coefficients utilized in this study may differ from the ones observed in the field due to variations on crop management such as row spacing and variety. Moreover, the $\mathrm{ET}_{\mathrm{O}}$ was calculated using the Hargreaves equation, which is based on restrict amount of weather variables and the daily values may differ from the real ones. However, most small farmers in Mozambique have no access to information and to water loss quantification, therefore these results are useful to assist them and should be used as a guideline to define crop water requirement for a growing season, especially when combined with ENSO forecast. This tool should be used together with local 
expertise from extension agents and growers. While there are several climate phenomena affecting the region, such as Indian Ocean Dipole, which may affect the rainfall occurrence [52], the ENSO conditions have a certain pattern of occurrence and can be forecasted in advance, making it useful for this type of study. Furthermore, this study is based on gridded data that are result of reanalysis and have coarse spatial resolution. Therefore, the tool may limit the information in regions with large elevation variability and should be interpreted for a whole region and not for a single pixel.

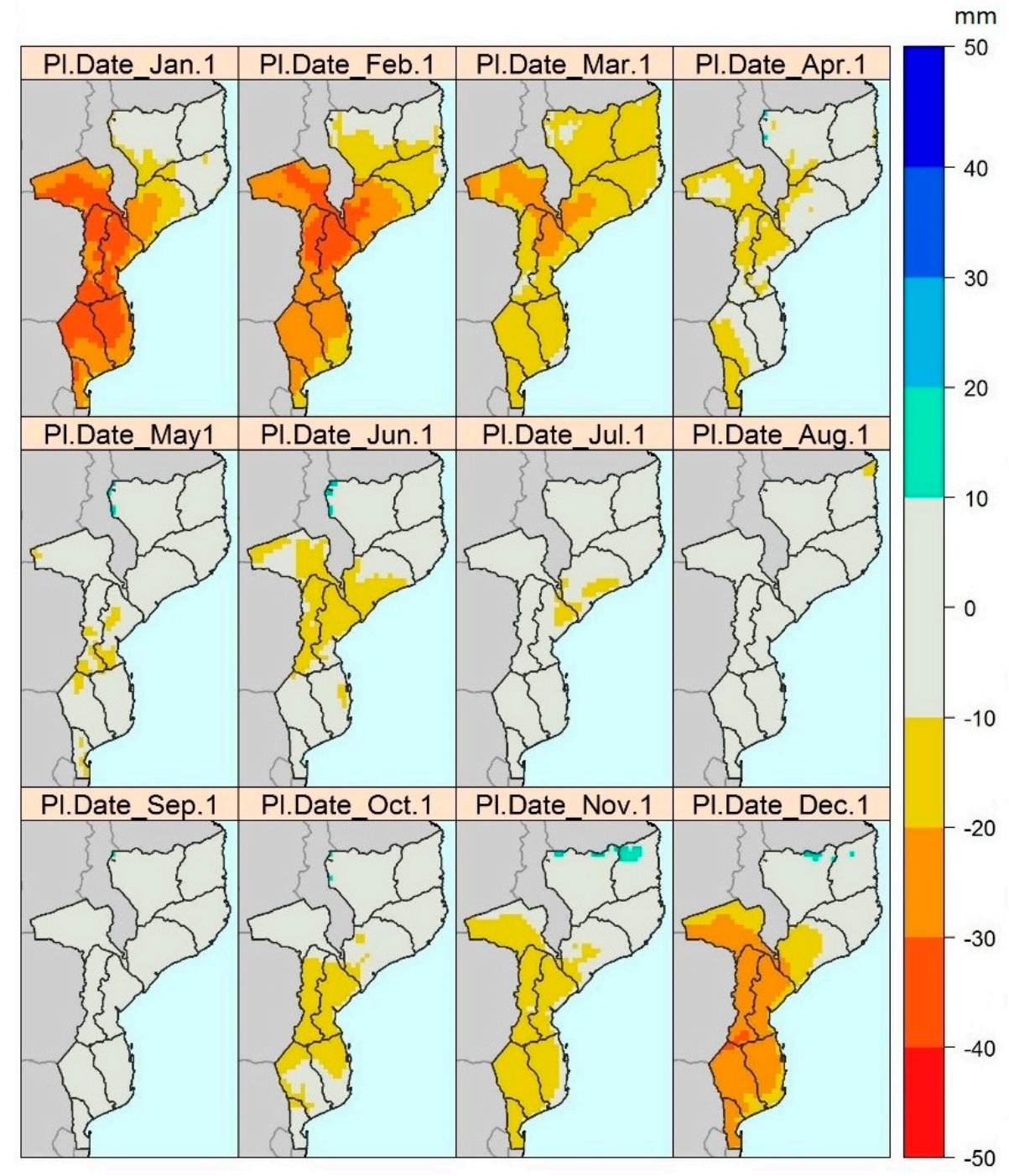

Figure 6. Spatial and temporal of deviation for La Niña of tomato crop total water requirement (mm) for Mozambique for a generic variety with 90-day growing cycle planted in the first day of each month.

\section{Conclusions}

ENSO-based irrigation schedule can assist farmers to better understand climate variability and plan the irrigation events considering inter-annual climate variability. ENSO-based decisions might be more useful from November to March, but it may improve irrigation schedule from April to June and contribute to maximize water use efficiency. El Niño was related to increased water use due to higher air temperatures and solar radiation, and lower relative humidity associated with it. The opposite was observed for La Niña, which was related to reduction in water requirements.

Crops planted from September to December have higher water requirement than crops planted during the remaining of the year. During this period, the total water use by the crop might be as high 
as $550 \mathrm{~mm}$. During the dry and cold season, the water need was lower, being as low as $250 \mathrm{~mm}$ in several parts of the country.

The irrigation tool in AgroClimate Mozambique was designed based on other tools that are widely used, and with the support of potential users. It has a user-friendly interface to display the water demand depending on the planting date, ENSO phase, and crop growing season length. While the tool does not consider real time data, it might be used by growers and extension agents to reduce the effects of dry spells and percolation during the rainy season, and reduces water stress and maximize the water use during the dry season.

Author Contributions: Conceptualization, E.G., C.W.F., L.Z., H.A.M. and C.C.E.; Data curation, E.G. and D.P.; Formal analysis, E.G.; Investigation, E.G.; Methodology, E.G., C.W.F., L.Z. and K.W.M.; Project administration, C.W.F. and L.Z.; Software, D.P.; Supervision, C.W.F. and L.Z.; Writing-original draft, E.G. and D.P.; Writing-review \& editing, E.G., C.W.F., L.Z., D.P., H.A.M., C.C.E. and K.W.M.

Funding: This research received no external funding.

Acknowledgments: This study and website (http://mz.agroclimate.org/) are made possible by the support of the American People through the United States Agency for International Development (USAID) under the Feed the Future Initiative. The contents of this study and website are the sole responsibility of authors and do not necessarily reflect the views of USAID or the United States Government.

Conflicts of Interest: The authors declare no conflict of interest.

\section{Appendix A}

Table A1. Three-month ENSO classification using the Oceanic Niño Index (ONI) where NE ( $\square$ ) is Neutral, EN ( $\square$ ) is El Niño and LN ( $\square$ ) is La Niña [53].

\begin{tabular}{|c|c|c|c|c|c|c|c|c|c|c|c|c|}
\hline Year & JFM & FMA & MAM & AMJ & MJJ & JJA & JAS & ASO & SON & OND & NDJ & DJF \\
\hline 1983 & EN & EN & EN & EN & EN & NE & NE & NE & NE & $\mathrm{NE}$ & $\mathrm{NE}$ & $\mathrm{NE}$ \\
\hline 1984 & NE & NE & NE & NE & $\mathrm{NE}$ & $\mathrm{NE}$ & NE & $\mathrm{NE}$ & LN & LN & LN & LN \\
\hline 1985 & LN & LN & LN & LN & LN & $\mathrm{NE}$ & NE & NE & NE & NE & NE & NE \\
\hline 1986 & NE & NE & NE & NE & $\mathrm{NE}$ & $\mathrm{NE}$ & NE & EN & EN & EN & EN & EN \\
\hline 1987 & EN & EN & EN & EN & EN & EN & EN & EN & EN & EN & EN & EN \\
\hline 1988 & EN & NE & $\mathrm{NE}$ & LN & LN & LN & LN & LN & LN & LN & LN & LN \\
\hline 1989 & LN & LN & LN & LN & $\mathrm{NE}$ & $\mathrm{NE}$ & NE & $\mathrm{NE}$ & $\mathrm{NE}$ & NE & NE & $\mathrm{NE}$ \\
\hline 1990 & NE & NE & NE & $\mathrm{NE}$ & NE & NE & NE & $\mathrm{NE}$ & NE & NE & NE & $\mathrm{NE}$ \\
\hline 1991 & NE & NE & NE & NE & EN & EN & EN & EN & EN & EN & EN & EN \\
\hline 1992 & EN & EN & EN & EN & EN & EN & NE & NE & NE & $\mathrm{NE}$ & NE & NE \\
\hline 1993 & NE & NE & NE & NE & NE & $\mathrm{NE}$ & NE & NE & NE & $\mathrm{NE}$ & NE & $\mathrm{NE}$ \\
\hline 1994 & NE & NE & NE & NE & $\mathrm{NE}$ & NE & $\mathrm{NE}$ & NE & EN & EN & EN & EN \\
\hline 1995 & EN & EN & NE & NE & $\mathrm{NE}$ & NE & LN & LN & LN & LN & LN & LN \\
\hline 1996 & LN & LN & NE & NE & $\mathrm{NE}$ & NE & $\mathrm{NE}$ & $\mathrm{NE}$ & NE & $\mathrm{NE}$ & NE & NE \\
\hline 1997 & NE & NE & NE & EN & EN & EN & EN & EN & EN & EN & EN & EN \\
\hline 1998 & EN & EN & EN & EN & $\mathrm{NE}$ & LN & LN & LN & LN & LN & LN & LN \\
\hline 1999 & LN & LN & LN & LN & LN & LN & LN & LN & LN & LN & LN & LN \\
\hline 2000 & LN & LN & LN & LN & LN & LN & LN & LN & LN & LN & LN & LN \\
\hline 2001 & LN & LN & NE & NE & NE & $\mathrm{NE}$ & NE & NE & NE & NE & NE & NE \\
\hline 2002 & NE & NE & NE & NE & EN & EN & EN & EN & EN & EN & EN & EN \\
\hline 2003 & EN & NE & NE & NE & $\mathrm{NE}$ & NE & NE & NE & NE & $\mathrm{NE}$ & NE & $\mathrm{NE}$ \\
\hline 2004 & NE & NE & $\mathrm{NE}$ & NE & NE & EN & EN & EN & EN & EN & EN & EN \\
\hline 2005 & EN & EN & EN & NE & NE & $\mathrm{NE}$ & NE & NE & NE & NE & NE & NE \\
\hline 2006 & NE & NE & $\mathrm{NE}$ & $\mathrm{NE}$ & NE & $\mathrm{NE}$ & NE & EN & EN & EN & EN & EN \\
\hline 2007 & NE & NE & NE & NE & NE & NE & LN & LN & LN & LN & LN & LN \\
\hline 2008 & LN & LN & LN & LN & LN & NE & NE & NE & NE & $\mathrm{NE}$ & $\mathrm{NE}$ & $\mathrm{NE}$ \\
\hline 2009 & $\mathrm{NE}$ & NE & NE & NE & $\mathrm{NE}$ & EN & EN & EN & EN & EN & EN & EN \\
\hline 2010 & EN & EN & EN & NE & NE & LN & LN & LN & LN & LN & LN & LN \\
\hline 2011 & LN & LN & LN & NE & $\mathrm{NE}$ & NE & LN & LN & LN & LN & LN & LN \\
\hline 2012 & LN & LN & $\mathrm{NE}$ & NE & $\mathrm{NE}$ & NE & NE & NE & NE & $\mathrm{NE}$ & NE & $\mathrm{NE}$ \\
\hline 2013 & $\mathrm{NE}$ & NE & $\mathrm{NE}$ & NE & $\mathrm{NE}$ & NE & NE & NE & NE & NE & NE & $\mathrm{NE}$ \\
\hline 2014 & NE & NE & NE & NE & $\mathrm{NE}$ & $\mathrm{NE}$ & NE & NE & NE & NE & NE & $\mathrm{NE}$ \\
\hline 2015 & NE & EN & EN & EN & EN & EN & EN & EN & EN & EN & EN & EN \\
\hline
\end{tabular}




\section{References}

1. Instituto Nacional de Estatística. Censo Agro-Pecuário 2009-2010: Resultados Preliminares; Instituto Nacional de Estatística: Maputo, Mozambique, 2011.

2. FAO FAOSTAT. Available online: http://www.fao.org/faostat/en/ (accessed on 25 March 2017).

3. Gelcer, E.; Fraisse, C.W.; Zotarelli, L.; Stevens, F.R.; Perondi, D.; Barreto, D.D.; Malia, H.A.; Ecole, C.C.; Montone, V.; Southworth, J. Influence of El Niño-Southern Oscillation (ENSO) on agroclimatic zoning for tomato in Mozambique. Agric. For. Meteorol. 2018, 248, 316-328. [CrossRef]

4. Ecole, C.C.; Malia, H.A. Caracterização da horticultura em Moçambique. In Horticultura em Moçambique: Características, Tecnologias de Produção e de Pós-Colheita; Haber, L.L., Ecole, C.C., Bowen, W., Resende, F.V., Eds.; EMBRAPA: Brasília, Brazil, 2015; pp. 21-31. ISBN 978-85-7035-515-7.

5. Henggeler, J.C.; Dukes, M.D.; Mecham, B.Q. Irrigation scheduling. In Irrigation, 6th ed.; Mecham, B.Q., Rochester, E.A., Ross, G.A., Sneed, R.E., Vinchesi, B.E., Eds.; Irrigation Association: Falls Church, VA, USA, 2011; pp. 491-564. ISBN 978-1-935324-50-8.

6. Patane, C.; Tringali, S.; Sortino, O. Effects of deficit irrigation on biomass, yield, water productivity and fruit quality of processing tomato under semi-arid Mediterranean climate conditions. Sci. Hortic. 2011, 129, 590-596. [CrossRef]

7. Allen, R.G.; Pereira, L.S.; Raes, D.; Smith, M. Crop Evapotranspiration-Guidelines for Computing Crop Water Requirements-FAO Irrigation and Drainage Paper 56; FAO: Rome, Italy, 1998.

8. Marouelli, W.A.; Silva, W.L.C.; Silva, H.R. Irrigação por Aspersão em Hortaliças: Qualidade da Água, Aspectos do Sistema e Métodos Práticos de Manejo, 2nd ed.; Embrapa Informação Tecnológica: Brasília, Brazil, 2008; ISBN 978-85-7383-428-4.

9. Fraisse, C.; Breuer, N.; Zierden, D.; Bellow, J.; Paz, J.; Cabrera, V.; Garcia y Garcia, A.; Ingram, K.; Hatch, U.; Hoogenboom, G.; et al. AgClimate: A climate forecast information system for agricultural risk management in the southeastern USA. Comput. Electron. Agric. 2006, 53, 13-27. [CrossRef]

10. Ropelewski, C.F.; Halpert, M.S. Global and regional scale precipitation patterns associated with the El Niño-Southern Oscillation. Mon. Weather Rev. 1987, 115, 1606-1626. [CrossRef]

11. Gelcer, E.; Fraisse, C.; Dzotsi, K.; Hu, Z.; Mendes, R.; Zotarelli, L. Effects of El Niño Southern Oscillation on the space-time variability of Agricultural Reference Index for Drought in midlatitudes. Agric. For. Meteorol. 2013, 174-175, 110-128. [CrossRef]

12. Stige, L.C.; Stave, J.; Chan, K.-S.; Ciannelli, L.; Pettorelli, N.; Glantz, M.; Herren, H.R.; Stenseth, N.C. The effect of climate variation on agro-pastoral production in Africa. Proc. Natl. Acad. Sci. USA 2006, 103, 3049-3053. [CrossRef]

13. Gaughan, A.E.; Staub, C.G.; Hoell, A.; Weaver, A.; Waylen, P.R. Inter- and Intra-annual precipitation variability and associated relationships to ENSO and the IOD in southern Africa. Int. J. Climatol. 2015, 36, 1643-1656. [CrossRef]

14. Lobo, J. Contribuição para o Estudo da Variabilidade Climática em Moçambique: A Influência do ENSO. Bachelor's Thesis, Universidade Eduardo Mondlane, Maputo, Mozambique, July 1999.

15. Mavie, A. Variabilidade climática inter-annual de Moçambique e sua Relação com o Fenómeno El-Niño-Oscilação Autral-Parte-II. Bachelor's Thesis, Universidade Eduardo Mondlane, Maputo, Mozambique, October 1999.

16. Gelcer, E.; Fraisse, C.W.; Zotarelli, L. Sistema de monitoramento climático: AgroClimate Moçambique. In Horticultura em Moçambique: Características, Tecnologias de Produção e de Pós-Colheita; Haber, L.L., Ecole, C.C., Bowen, W., Resende, F.V., Eds.; EMBRAPA: Brasília, Brazil, 2015; pp. 213-218. ISBN 978-85-7035-515-7.

17. Tadross, M.; Suarez, P.; Lotsch, A.; Hachigonta, S.; Mdoka, M.; Unganai, L.; Lucio, F.; Kamdonyo, D.; Muchinda, M. Growing-season rainfall and scenarios of future change in southeast Africa: Implications for cultivating maize. Clim. Res. 2009, 40, 147-161. [CrossRef]

18. Fraisse, C.; Zierden, D.; Breuer, N.; Jackson, J.; Brown, C. Climate Forecast and Decision Making in Agriculture; ABE252; University of Florida: Gainesville, FL, USA, 2004.

19. Battilani, A.; Bussières, P.; Dumas, Y. IRRIGERE: An improved version of an irrigation scheduling model for the processing tomato crop. Acta Hortic. 2000, 537, 519-526. [CrossRef]

20. Muñoz-Carpena, R.; Dukes, M.D.; Li, Y.C.; Klassen, W. Field comparison of tensiometer and granular matrix sensor automatic drip irrigation on tomato. Horttechnology 2005, 15, 584-590. 
21. Davis, S.L.; Dukes, M.D.; Miller, G.L. Landscape irrigation by evapotranspiration-based irrigation controllers under dry conditions in Southwest Florida. Agric. Water Manag. 2009, 96, 1828-1836. [CrossRef]

22. Migliaccio, K.W.; Morgan, K.T.; Fraisse, C.; Vellidis, G.; Andreis, J.H. Performance evaluation of urban turf irrigation smartphone app. Comput. Electron. Agric. 2015, 118, 136-142. [CrossRef]

23. Vellidis, G.; Liakos, V.; Andreis, J.H.; Perry, C.D.; Porter, W.M.; Barnes, E.M.; Morgan, K.T.; Fraisse, C.; Migliaccio, K.W. Development and assessment of a smartphone application for irrigation scheduling in cotton. Comput. Electron. Agric. 2016, 127, 248-259. [CrossRef]

24. Saetre, R.; Silva, R.P. The Marine Fish Resources of Mozambique-Reports on Surveys with R/V Dr. Fritjof Nansen; Serviço de Investigações Pesqueiras: Maputo, Mozambique; Mozambique and Institute of Marine Research: Bergen, Norway, 1979.

25. Kottek, M.; Grieser, J.; Beck, C.; Rudolf, B.; Rubel, F. World Map of the Köppen-Geiger climate classification updated. Meteorol. Z. 2006, 15, 259-263. [CrossRef]

26. Hoguane, A. Perfil diagnóstico da Zona Costeira de Moçambique. Revista da Gestão Costeira Integrada 2007, 7, 69-82. [CrossRef]

27. Doorenbos, J.; Kassam, A.H. Yield Response to Water-FAO Irrigation and Drainage Paper 33; FAO: Rome, Italy, 1979.

28. Hargreaves, G.H.; Samani, Z.A. Reference crop evapotranspiration from temperature. Appl. Eng. Agric. 1985, 1, 96-99. [CrossRef]

29. Farmer, W.; Strzepek, K.; Schlosser, C.A.; Droogers, P.; Xiang, G.A. Method for Calculating Reference Evapotranspiration on Daily Time Scales Report 195; MIT Joint Program on the Science and Policy of Global Change: Cambridge, MA, USA, 2011.

30. Droogers, P.; Allen, R.G. Estimating reference evapotranspiration under inaccurate data conditions. Irrig. Drain. Syst. 2002, 16, 33-45. [CrossRef]

31. Saha, S.; Moorthi, S.; Pan, H.-L.; Wu, X.; Wang, J.; Nadiga, S.; Tripp, P.; Kistler, R.; Woollen, J.; Behringer, D.; et al. The NCEP Climate Forecast System Reanalysis. Bull. Am. Meteorol. Soc. 2010, 91, 1015-1058. [CrossRef]

32. Marouelli, W.A.; Silva, W.L.C.; Silva, H.R. Manejo de Irrigação em Hortaliças, 5th ed.; Embrapa Centro Nacional de Pesquisa de Hortaliças: Brasília, Brazil, 1996; ISBN 85-85007-27-3.

33. Woli, P.; Jones, J.W.; Ingram, K.T.; Fraisse, C.W. Agricultural Reference Index for Drought (ARID). Agron. J. 2012, 104, 287-300. [CrossRef]

34. Hengl, T.; de Jesus, J.M.; MacMillan, R.A.; Batjes, N.H.; Heuvelink, G.B.M.; Ribeiro, E.; Samuel-Rosa, A.; Kempen, B.; Leenaars, J.G.B.; Walsh, M.G.; et al. SoilGrids1km—Global Soil Information Based on Automated Mapping. PLoS ONE 2014, 9. [CrossRef]

35. Rawls, W.J.; Brakensiek, D.L.; Saxton, K.E. Estimation of Soil Water Properties. Trans. ASAE 1982, 25, 1316-1320, 1328. [CrossRef]

36. Dukes, M.D.; Zotarelli, L.; Morgan, K.T. Use of irrigation technologies for vegetable crops in Florida. Horttechnology 2010, 20, 133-142.

37. Pilgrim, M. HTML5: Up and Running; O'Reilly Media: Sebastopol, CA, USA, 2010; ISBN 978-0-596-80602-6.

38. Meyer, E.A. CSS: The Definitive Guide, 3rd ed.; O'Reilly Media: Sebastopol, CA, USA, 2006; ISBN 978-0-596-52733-4.

39. Flanagan, D. JavaScript: The Definitive Guide, 5th ed.; O'Reilly Media: Sebastopol, CA, USA, 2006; ISBN 978-0-596-80552-4.

40. Florida Automated Weather Network. Available online: https://fawn.ifas.ufl.edu/ (accessed on 25 November 2015).

41. Bonachela, S.; Gonzalez, A.M.; Fernandez, M.D. Irrigation scheduling of plastic greenhouse vegetable crops based on historical weather data. Irrig. Sci. 2006, 25, 53-62. [CrossRef]

42. Amayreh, J.; Al-Abed, N. Developing crop coefficients for field-grown tomato (Lycopersicon esculentum Mill.) under drip irrigation with black plastic mulch. Agric. Water Manag. 2005, 73, 247-254. [CrossRef]

43. Mbabazi, D.; Migliaccio, K.W.; Crane, J.H.; Fraisse, C.; Zotarelli, L.; Morgan, K.T.; Kiggundu, N. An irrigation schedule testing model for optimization of the Smartirrigation avocado app. Agric. Water Manag. 2017, 179, 390-400. [CrossRef]

44. Zotarelli, L.; Scholberg, J.M.; Dukes, M.D.; Muñoz-Carpena, R.; Icerman, J. Tomato yield, biomass accumulation, root distribution and irrigation water use efficiency on a sandy soil, as affected by nitrogen rate and irrigation scheduling. Agric. Water Manag. 2009, 96, 23-34. [CrossRef] 
45. Wang, D.; Kang, Y.; Wan, S. Effect of soil matric potential on tomato yield and water use under drip irrigation condition. Agric. Water Manag. 2007, 87, 180-186. [CrossRef]

46. Marouelli, W.A.; Silva, W.L.C. Tomateiro Para Processamento Industrial: Irrigacao e Fertirrigação por Gotejamento-Circular Técnica 30; Embrapa Hortaliças: Brasilia, Brazil, 2002.

47. Brito, M.E.B.; Soares, L.A.A.; Lima, G.S.; Sá, F.V.S.; Araujo, T.T.; Silva, E.C.B. Crescimento e formação de fitomassa do tomateiro sob estresse hídrico nas fases fenológicas. Irriga 2015, 20, 139-153. [CrossRef]

48. May, D.M. Moisture stress to maximize processing tomato yield and fruit quality. Acta Hortic. 1993, 335, 547-552. [CrossRef]

49. FAO/IIASA/ISRIC/ISSCAS/JRC. Harmonized World Soil Database (Version 1.2); FAO: Rome, Italy; IIASA: Laxenburg, Austria, 2012.

50. EMBRAPA Hortaliças Cultivo de Tomate para Industrialização. Available online: https:// sistemasdeproducao.cnptia.embrapa.br/FontesHTML/Tomate/TomateIndustrial_2ed/index.htm (accessed on 14 May 2017). (In Portuguese)

51. Johane, S. Comportamento de Preços de Algumas Hortícolas no Mercado Central de Maputo (1998-2004). Bachelor's Thesis, Universidade Eduardo Mondlane, Maputo, Mozambique, June 2007.

52. Saji, N.H.; Yamagata, T. Possible impacts of Indian Ocean Dipole mode events on global climate. Clim. Res. 2003, 25, 151-169. [CrossRef]

53. Climate Prediction Center (CPC) Cold \& warm episodes by season. Available online: http:/ /www.cpc.noaa. gov/products/analysis_monitoring/ensostuff/ensoyears.shtml (accessed on 8 February 2017).

(C) 2018 by the authors. Licensee MDPI, Basel, Switzerland. This article is an open access article distributed under the terms and conditions of the Creative Commons Attribution (CC BY) license (http:/ / creativecommons.org/licenses/by/4.0/). 